\title{
MENINGKATKAN KETERAMPILAN DASAR MENGAJAR GURU DALAM PENGEMBANGAN SUPERVISI KLINIS
}

\author{
SRI DIANA PUTRI \\ sridianaputri12@gmail.com
}

\begin{abstract}
ABSTRAK
Penelitian ini bertujuan untuk mngetahui bagaimana perkembangan pemahaman sekolah tentang teknis supervisi klinis, dan juga cara mengembangkan teknik klinis tersebut dan juga bagaimana keterampilan dalam mengajar.

Penelitian yang dilakukan menggunakan pndekatan kualitatif dengan jenis penelitiannya pengembangan. Yang jadi subjek penelitian disini adalah kepala sekolah dan beberapa orang guru. Hasil dalam penelitian ini menunjukkan bahwa dalam pemahaman kpala sekolah terhadap studi awal trhadap supervisi klinis kurang bagus. Setelah melakukan penelitian yang berkembang dengan sangat baik barulah mampu dilaksanakan supervisi klinis secara tepat, sehingga hambatan yang terjadi dalam keterampilan belajar dapat teratasi dengan baik.

Dalam meningkatkan dan mengembangkan kegiatan pembelajaran yang lebih kondusif diperlukannya adanya supervisi. Namun beberapa guru merasa takut, resah karna pada umunya supervisi bersumber pada prilaku supervisi yang akan dilkukan oleh kepala sekolah . agar dalam proses pembelajaran dapat berjalan dengan semestinya dan dapat mengurangi masalah.bahwa sama-sama kita ketahui guru merupakan komponen yang paling penting dalam pelaksanaan kegitan pendidikan

Kepala sekolah yang bertindak sebagai supervisor seharusnya bisa memilih dan mnggunakan supervisi sesuai dngan apa yang dibutuhkan oleh guru.dan begitu juga sebaliknya guru yang masih memiliki ketrampilan yang lemah atatu kurang dapat menggunakan dibantu dngan teknik supervisi klinis.
\end{abstract}

Kata kunci : supervisi klinis, keterampilan dasar mengajar, kepala sekolah

\section{LANTAR BELAKANG}

Perlu diketahui bahwa supervisi memiliki arti yang sangat penting untuk menegembangkan dan meningkatkan dalam proses pembelajaran. Tetapi ada beberapa guru yang kurang menyukai kegiatan supervisi karena merasa resah dan juga takut dan selalu menghindar kalau dilakukannya kegiatan supervisi ini. oleh sebab itu Kepala sekolah selaku supervisor seharusnya dapat menentukan mana model supervisi yang sesuai dengan kebutuhan guru yang masih memiliki keteramapilan mengajar yang masih lemah agar dapat dibantu dengan adanya teknis supervisi klinis. Berdasar permasalahan di atas, maka perlu dilakukan penelitian tentang pengembangan supervisi klinis untuk meningkatkan keterampilan dasar mengajar seorang guru. 
Model supervisi klinis ini lebih mengutamakan pada hubungan tatap muka antara supervisor dengan guru serta serta juga terpusat pada perilaku sesungguhnya dari seorang guru dalam mengajar, agar apa yang diajarkan dapat diapahami oleh siswanya. Jadi supervisi klinis ini dapat membantu guru dalam mengurangi adanya kesenjangan yang terjadi antara proses mengajar yang nyata dengan proses belajar yang seharusnya terjadi.supervisi klnis bukan hanya untuk tujuan administrasi tapi lebih pada meningkatkan kemampuan seorang guru agar lebih optimal lagi dalam mengajar .sehingga memberikan prubahan yang jauh lebih bagus . jadi dapat disimpulkan bahawa supervisi klinis adalah untuk memperbaiki dan meningkatkan perilaku mengajar guru, terutama yang lemah dalam mengajar para siswa.

Posisi guru sangat penting sekali dalam proses belajar sebab gurulah yang akan mengolah bagaimana cara melibatkan siswa agar turut aktif dalam proses pembelajaran,agar semua kerjaan guru bisa berjalan dengan lancar .jadi guru tersebut harus memiliki keterampilan mengajar yang baik.karena keterampilan mengajar yang baik adalah kemampuan yang dapat dipelajari serta diterapkan oleh setiap guru. Jika seorang guru dapat menerapkan keterampilan dasar mengajar secara tepat, maka akan dapat menumbuhkan suasana pembelajaran yang menyenangkan dan aktif, sehingga guru akan dapat meningkatkan mutu pembelajaran yang sesuai.

Seperti dikemukakan Underwood (1987) keterampilan mengajar yang baik akan sangat mempengaruhi cara siswa memandang anda dan pada gilirannya akan mempengaruhi perilaku mereka dalam belajar.jadi disini antara supervisi klinis dengan ketermpilan mengajar seorang guru memiliki keterkaitan yang sangat erat yaitu merupakan salah satu alternatif untuk membantu guru dalam meningkatkan keterampilan dasar mengajar, karena konsep supervisi klinis memang ditujukan untuk memperbaiki aspek-aspek yang menyebabkab guru kurang dapat mengajar dengan baik.

Berdasarkan uraian diatas permasalahan pada tulisan ini adalah (1) bagaimana Pemahaman Kepala Sekolah terhadap Supervisi Klinis ? (2) bagaimana Pelaksanaan Supervisi Klinis seharusnya terjadi?. Tujuan tulisan ini adalah untuk membantu guru dalam meningkatkan keterampilan dasar mengajar, karena konsep supervisi klinis memang ditujukan untuk memperbaiki aspek-aspek yang menyebabkab guru kurang dapat mengajar dengan baik.

\section{KAJIAN LITERATUR}

Perkembangan ilmu pengetahuan terus maju seiring dengan perkembangan supervisi pendidikan,sebagaimana yang dikemukakan oleh sabandi (sabandi, 2013) karena perkembangan ilmu pengetahuan meliputi tekonologi, sosial, budaya masyarakat dan juga ekonomi. Berkembang dalam perpaduan antara supervisor dan guru yang bersama-sama meningkatkan kualitas pembelajar agar membangkitkan budaya belajar pada seorang guru agar selalu meningkatkan kompetensimya.

Meskipun supervisi klinis mengalami perkembangan, tema umumnya adala $h$ peningkatan kolegialitas dan kualitas guru. Perbedaan dalam perkembangannya berhubungan deng an siklus atau urutan, fokus pada isi atau proses, variasi dalam penggunaan teknik tertentu, metode dan proses, penekanan pada hubungan inter 
personal, dan perbedaan pendekatan pengumpul an data atau keragaman konsepsi mengajar.(sabandi, 2013)

Adapun mengenai kompetensi guru,Undang-UndangNomor 14 Tahun 2005 tentang Guru dan Dosen mengemukakan bahwa seorang guru adalah pendidik professional dengan tugas utama mendidik, mengajar, membimbing, mengarahkan, melatih, menilai, dan mengevaluasi peserta didik pada jalur pendidikan formal, pendidikan dasar, dan pendidikan menengah. (Astuti, 2016)

\section{PEMBAHASAN}

Meningkatkan dan mengembangkan kegiatan pembelajaran yang lebih kondusif diperlukannya adanya supervisi. Namun beberapa guru merasa takut, resah karna pada umunya supervisi bersumber pada prilaku supervisi yang akan dilkukan oleh kepala sekolah . agar dalam proses pembelajaran dapat berjalan dengan semestinya dan dapat mengurangi masalah.bahwa sama-sama kita ketahui guru merupakan komponen yang paling penting dalam pelaksanaan kegitan pendidikan.

Kepala sekolah yang bertindak sebagai supervisor seharusnya bisa memilih dan mnggunakan supervisi sesuai dngan apa yang dibutuhkan oleh guru.dan begitu juga sebaliknya guru yang masih memiliki ketrampilan yang lemah atatu kurang dapat menggunakan dibantu dngan teknik supervisi klinis.

Model supervisi klinis ini lebih mengutamakan pada hubungan tatap muka antara supervisor dengan guru serta serta juga terpusat pada perilaku sesungguhnya dari seorang guru dalam mengajar, agar apa yang diajarkan dapat diapahami oleh siswanya. Jadi supervisi klinis ini dapat membantu guru dalam mengurangi adanya kesenjangan yang terjadi antara proses mengajar yang nyata dengan proses belajar yang seharusnya terjadi.supervisi klinis bukan hanya untuk tujuan administrasi tapi lebih pada meningkatkan kemampuan seorang guru agar lebih optimal lagi dalam mengajar .sehingga memberikan prubahan yang jauh lebih bagus . jadi dapat disimpulkan bahawa supervisi klinis adalah untuk memperbaiki dan meningkatkan perilaku mengajar guru, terutama yang lemah dalam mengajar para siswa.

\section{HASIL PEMBAHASAN}

Pemahaman Kepala Sekolah terhadap Supervisi Klinis

Sebelumnya kepala skolah tidak tahu bagaimana cara memahami konsep supervisi klinis yang akan diterapkannya kepada guru, agar guru tersebut dapat meningktakan proses mengajar kepada para siswa.tetapi setelah dilakukannya pengembangan kepada kepala sekolah bagaimana konsep suprvisi klinis yang benar, barulah kepala sekolah mengerti tentang proses, tujuan,prinsip supervisi klinis beserta tujuannya agar dapat mudah menjalankan sesuai dengan ketentuan yang ada.Siklus selanjutnya kepala sekolah sudah benar-benar dapat memahami bagaimana supervisi klinis tersebut, dan merasakan manfaat yang banyak dari supervisi tersebut. 


\section{Pelaksanaan Supervisi Klinis}

Sebelum kepala sekolah tidak pernah mengembangan maupun melaksanakan supervisi klinis, jika supervisi kunjungan kelas digunakan dengan langkah : mensosialisasikan dan menyusun jadwal supervisi, memberi pembinaan pada guru dan mengadakan kunjungan kelas.

kepala sekolah dapat melakukan pengembangan dapat melaksanakan supervisi klinis dengan sangat baik. Langkah-langkah yang ditempuh oleh kepala sekolah sudah sesuai dengan pendapat Sahertian (2000) serta Bollington, Nurtain (1989), Hopkins dan West (1990) yang menyatakan tiga langkah supervisi klinis, yaitu : (1) tahap pertemuan awal atau perencanaan, (2) tahap pelaksanaan supervisi, dan (3) tahap pertemuan akhir atau balikan.

\section{PENUTUP}

\section{SIMPULAN}

awalnya kepala sekolah kurang mengembangkan dan memahami apa yang dilakukan terhadap teknik supervisi klinis agar menjadi lebih baik. Tetapi Setelah dilakukan pengembangan, pada siklus pertama kepala sekolah dapat memahami konsep supervisi klinis tetapi masih belum bisa melaksanakan secara baik. Selanjutnya siklus kedua kepala sekolah sudah bisa mengurangi kelemahan yang terjadi pada siklus pertama, dan pada siklus terakhir kepala sekolah dapat melaksanakan supervisi klinis dengan sangat baik.

Sebelum dilakukan pengembangan, kepala sekolah tidak mengerti mengenai langkah-langkah pelaksanaan supervisi klinis. Setelah dilakukan pengembangan kepala sekolah dapat melaksanakan supervisi klinis yang meliputi tahap pertemuan awal atau perencanaan,tetapi setelah dilakukan pemahaman kepala sekolah mulai paham bagaimana langkah-langkah agar supervisi klini yang diterapkan dapat berjalan dengan baik dan juga dapat mengurangi kekurangan yang terjadi kepada guru saat proses belajar mengajar.

\section{SARAN}

Kepala Sekolah Selaku supervisor, hendaknya lebih tanggap dan peka terhadap kekurangan -kekurangan yang terjadi terhadap guru dalam proses pembelajaran, sehingga dapat mengurangi permasalahn yang trjadi dan juga langsung diberikan bantuan berupa supervisi klinis terhadap guru yang kondisinya sangat lemah atau kronis. Sehingga proses mengajar dapat berjalan sebagaimna yang diharapkan 


\section{REFERENSI}

Astuti, S. (2016). Supervisi Akademik Untuk Menigkatkan Kompetensi Guru Di Sd Laboratorium Uksw. Scholaria, Jurnal Pendidikan Dan Kebudayaan, 6(1), 117126. Retrieved From Http://Ejournal.Uksw.Edu/Scholaria/Article/View/713

Sabandi, Ahmad. (2013). Supervisi Pendidikan Untuk Pengembangan Profesionalitas

Guru Supervisi Pendidikan Untuk Pengembangan Profesionalitas Guru Berkelanjutan. Pedagogi,Jurnal Ilmiah Ilmu Pendidikan, Xiii(2), 1-9. Retrieved From Http://Ejournal.Unp.Ac.Id/Index.Php/Pedagogi/Article/View/4275/3345 